
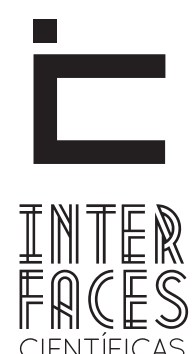

HUMANASE SOCIAIS

ISSN IMPRESSO 2316-3348

E-ISSN 2316-3801

DOI - 10.17564/2316-3801.2016v4n3p43-58

\title{
AVATARES CINEMATOGRÁFICOS PEREGRINAM ENTRE A CIDADE E A ROÇA: KIDWOOD, ZÉ KINOSCÓPIO E ANA CINÉSIA EM PELEJA FURIOSA.
}

SEE FILM AVATARS BETWEEN THE CITY AND THE FARM: KIDWOOD, ZÉ DIRETOR AND ANA CINÉSIA IN BATTLE FURIOUS. AVATARES CINEMATOGRÁFICOS PEREGRINAM ENTRE LA CIUDAD Y LA GRANJA: KIDWOOD, ZÉ KINOSCÓPIO

Y ANA CINÉSIA EN BATALLA FURIOSA.

\section{RESUMO}

Propomos refletir sobre o contraste entre territórios caracterizados pelos arquétipos da cidade moderna, da sociedade cosmopolita, da urbanidade e civilidade e pelos arquétipos do sertão, da comunidade, da roça, da vila. Assume-se nessa comunicação que esses arquétipos expressam determinações simbólicas de dominação e negociação entre si. Essas determinações podem se expressar através de escopos, conjuntos discursivos da narração cinematográfica, caracterizados por certas determinações: centro/periferia, primeiro mundo/terceiro mundo; local/global. Respondendo ao jogo discursivo que se pretende efetuar aqui, esses territórios serão inscritos por três avatares, alegorias ou sujeitos discursivos cinematográficos que interpretam, cada qual, o escopo discursivo de si e de seus outros buscando instituir uma peleja: Kidwood, o macho ibero-americano, Zé Kinoscópio, o intelectual revolucionário da periferia e Ana Cinésia, a andeja feminista dos não-lugares.

\section{PALAVRAS-CHAVE}

Cinema. Identidade. Território. Dominação. Feminino. 


\section{ABSTRACT}

We propose reflect on the contrast between are as characterized by the archetypes of the modern city, cosmopolitan society of urbanity and civility and the archetypes of the backwoods, of the community, of the farm village. It is assumed in this communication that these archetypes express symbolic determinations of domination and negotiation with each other. These determinations can express themselves through scopes, discursive sets of cinematic storytelling, characterized by certain determinations: Center/periphery, first world/third world; local/global. Responding to the discursive game intended to perform here, these terri- tories will be entered by three avatars, allegories or discursive subjects who interpret, each film, the discursive scope of themselves and of their other seeking a battle: Kidwood, the ibero-American male, Zé Kinoscópio, the revolutionary intellectual from the periphery and Ana Cinésia, the feminist stroller of non-places.

\section{KEYWORDS}

Cinema. Identity. Territory. Domination. Female.

\section{RESUMEN}

Se propone reflexionar sobre el contraste entre áreas caracterizadas por los arquetipos de la ciudad moderna, de la sociedad cosmopolita, de la urbanidad y cortesía y por los arquetipos del sertón, de la comunidad, de la aldea, de la granja. En esta comunicación se asume que estos arquetipos expresan determinaciones simbólicas de dominación y de negociación con los demás. Estas determinaciones pueden expresarse a través de ámbitos, sistemas discursivos de narración cinematográfica, caracterizado por ciertas determinaciones: centro/periferia, primer mundo/tercer mundo; local/global. En respuesta al juego discursivo que pretende realizar aquí, estos territorios se incorporarán tres avatares, alegorías o sujetos discursivos que interpretan, cada película, el ámbito discursivo de los mismos y de sus otras buscando una batalla: Kidwood, el hombre Iberoamericano, Zé Diretor, el intelectual revolucionario de la periferia y Ana Cinésia, la feminista viajante de los no lugares.

\section{PALABRAS CLAVE}

Cine. Identidad. Territorio. Dominación. Hembra. 


\section{INTRODUÇ̄̃̃}

Sobre o tratamento da linguagem e seus modos de dizer e ouvir, dois aspectos deleuzianos serão relevantes neste artigo:

O primeiro consiste em pensar a linguagem no âmbito de sua doutrina paradoxal das faculdades. [...] os procedimentos literários levam a linguagem a um limite não no sentido de sua limitação de forma, de margem ou de fronteira, mas de grau de potência, como aquilo a partir do qual ela desenvolve sua potencia [...] e vai até o fim do que ela pode, atinge sua enésima potencia, seu limiar de intensidade. Trata-se, portanto de um limite agramatical - intensivo - que devasta as designações e significações, permitindo que a linguagem deixe de ser representativa e adquira a potência de dizer o que é indizível para a linguagem empírica ou habitual [...] O segundo elemento [...]: a criação de uma língua estrangeira na própria língua, faz com que ela adquira um estado de tensão em direção a alguma coisa que não é sintática nem mesmo diz respeito a linguagem: um de-fora da linguagem. O de-fora da linguagem, que não se reduz à exterioridade nem à interioridade, aparece aqui como vida e como saber. (MACHADO, 2010, p. 211).

$\mathrm{O}$ artigo trata de uma peleja entre Kidwood, Zé Kinoscópio e Ana Cinésia. Kidwood expressa o conjunto discursivo referente ao cinema estadunidense, industrial, com seus arquétipos bem resolvidos, herói, bandido, sacrifício, recompensa, telos. Tudo muito bem definido, sem final aberto. Zé Kinoscópio expressa o conjunto discursivo do cinema autoral, independente, muito presente no terceiro mundo, cinema pós-colonial, político, intelectual, cinema de reinvenção das identidades, mas algo de heroico, herança patriarcal, machista, ainda sobrevive nesse conjunto.

Ana Cinésia entra na peleja, expressando o conjunto discursivo que fala a partir do feminino, denunciando o machismo expresso de modo desavergonhado em Kidwood e, o mais surpreendente, ainda que de forma mais tênue, também presente em Kinoscópio, na forma, por exemplo, de certa herança ibericado homem sul-americano. Os três conjuntos discursivos do dizer cinematográficopodem falar como: sujeitos discursivos, categoria de Bakhtin (2003), como alegorias, categorias de Walter Benjamin(1984) e, finalmente, como avatares, no sentido proposto pelo pós-estruturalismo, isto é, escopo discursivo que trabalha, adiando toda tentativa de determinar um sentido final para os discursos aqui elencados ${ }^{1}$. Cabe aos leitores interpretá-los da maneira que melhor lhes convier.

Com base em Bakhtin, utilizamos da marcação de posição de sujeito em que o discurso reproduz um significado interno e um sentido externo em relação dialógica com seus interlocutores e contexto (social, cultural, político, moral, tecnológico etc.). Segundo Bakhtin, todo discurso prevê um interlocutor (quem fala sempre fala para alguém, mesmo um eu imaginário) e, nessa prática entre emissor e receptor, o discurso alcança um sentido dialógico quando expressa elementos incorporados do que o emissor imagina ser a resposta que o receptor produzirá ao receber a mensagem.

Esse jogo em que a fala do receptor já está incorporada ao discurso do emissor é o que Bakhtin chama de dialogismo, componente importante na elaboração de um quadro semiótico da posição de sujeito de determinado sujeito discursivo. Dentro dessa linha mais estruturada, seria possível, por exemplo, separar a parte do discurso que revela a posição política do emissor, se conservadora ou liberal ou revolucionária, da parte em que está tentando negociar com seu interlocutor, mas que, de fato, não reflete aquilo que verdadeiramente quer dizer.

Com base em Benjamin, operamos pelo conceito de alegoria que rompe com a ideia do sujeito histórico, preso ao tempo e ao contexto de sua época. A alegoria benjaminiana serve de inspiração para certa tomada

1. 0 pós-estruturalismo também especifica um conjunto de autores e discursos rasurados e aglutinados por características comuns, por exemplo, como forças de desconstrução/deslocamento de certos paradigmas da modernidade. 
de posição pós-estruturalista, considerando que "as alegorias são no reino dos pensamentos o que são as ruínas no reino das coisas” (BENJAMIN, 1984, p. 200). Essa imagem da ruina traz a imprevisibilidade dos efeitos de rastro, rasura e linha de fuga operando sobre os signos ou as coisas, cuja descriminação, não interessa.

O ser alegórico moderno já seria o prenuncio desse sujeito fragmentado, desconstruído, deslizante, movido pelos anacolutismos das narrativas do cinema da Nouvelle Vague, cinema da imagem-tempo de Deleuze, por sua vez, inspirado no existencialismo de Sartre. 0 sujeito rasurado que não cabe nos paradigmas do pensamento clássico, nem na tradição medieva, nem no ideal romântico parnasiano. 0 ser alegórico é multifacetado, capaz de trair a si mesmo. Suas conviç̧ões e ideais são contingenciais e não cabem em uma moral pré-determinada, seja pelo bem platônico, seja pelo Deus cristão, seja pela honra à pátria.

Tomando o exemplo do flanêur, como figura alegórica benjaminiana, ele pode estar e não estar na multidão, isto é, pode se comprometer e em um átimo se descomprometer das forças de reprodução do capital que se articulam dentro dessa multidão. Benjamin não nega o pensamento marxista, no sentido em que é sensível à exploração e à alienação do trabalhador dentro do modo de produção capitalista. Porém, não se limita à análise do indivíduo encapsulado pelo conceito de classe social. Da mesma forma, se para Marx, a arte se encontra na superestrutura como consequência do modo de produção de uma sociedade, para Benjamin, ela ocupa um lugar estratégico nas formas de dominação e reprodução da sociedade capitalista.

Os avatares, no sentido pós-estruturalista, apontam para a impossibilidade de determinar a origem, 0 sentido e o significado fim de um discurso no mundo. Também expressam uma impossibilidade de apontar o sujeito-autor no mundo, confundindo personagem, persona, pessoa, assim como, autor, texto e leitor. Segundo esse escopo critico, o ato da leitura de um texto já especifica e incorpora a produção de novos senti- dos, tradução, marca, rasura sobre o discurso-texto que, como coisa no mundo, já desfruta de autonomia, encontra-se já despregado em relação às intenções que o autor pré-determinava durante sua produção.

Rasura, grama e rastro desautorizam paradigmas ao mesmo tempo em que abrem possibilidades para novas interpretações discursivas. Os termos derridianos expressam as origens rasuradas dos discursos dos avatares e, por isso, inscrevem no discurso-texto a condição de possibilidade de ouvirmos Ana Cinésia, Kidwood e Zé Kinoscópio, avatares que se tornam sujeitos nem mais nem menos reais ou metafísicos que qualquer sujeito, todos os sujeitos, o sujeito, o altere, o contexto, o conceito.

Nem mais nem menos inventados e falantes que o capitalista, o trabalhador e as classes sociais de Marx a Durkheim, que o tipo-ideal weberiano, que os a priori kantianos e o espírito hegeliano, que a mão-invisível de Adam Smith, que o super-homem de Nietzsche, que a alegoria de Benjamin, que o ser e o ente de Heidegger, que o intelectual orgânico de Gramsci, que as pastoras do catolicismo popular, mesmo a Diana e a borboleta, que o boitatá e o curupira do folclore brasileiro, que os santos, orixás, Jesus, Buda e tantos mestres de saberes não-laicos (dos quais, a alguns, devotamos nossa fé incondicional), que os personagens históricos de Tiradentes a Nero, que os personagens da ficção Dom Casmurro e Dom Quixote, sem o qual não haveria Cervantes, como bem observou Haddock-Lobo (2008). Salvo a condição de nome, qual outra autoridade os qualifica como distinções hierarquizadas?

Ao término da voz e o fenômeno Derrida, comentando a famosa epígrafe de Husserl, nos dá uma pista para pensar o labirinto do qual o pensamento racional tenta, por meio das estratégias da razão e da determinação do que está compreendido, esquivar-se sem sucesso.

Sem dúvida, tudo começou assim: um nome pronunciado diante de nós transporta-nos à galeria de Dresde. Erramos pelas salas... Uma tela de Téniers... representa uma galeria de quadros... Os quadros dessa 
galeria representam, por sua vez, quadros que revelam inscrições passíveis de ser decifradas etc. Certamente nada procedeu nessa situação. Seguramente, nada a suspenderá. Ela não está compreendida como o desejaria Husserl, entre as intuições ou apresentações. Da plena luz da presença, fora da galeria, nenhuma percepção nos é dada, nem, certamente, prometidas. A galeria é o labirinto que compreende em si suas saídas: nunca se cai ali como em um caso particular de experiência, aquele que Husserl acreditava descrever então. [...] Então resta falar, fazer ressoar a voz nos corredores, para suprir o brilho da presença. O fonema, a akumene, é o fenômeno do labirinto. Esse é o caso da phoné. Elevando-se em direção ao sol da presença, ela é o caminho de Ícaro. [...] E ao contrário do que a fenomenologia - que é sempre fenomenologia da percepção - tentou nos fazer acreditar, ao contrário do que nosso desejo não pode deixar de ser tentado a crer, a própria coisa se esquiva sempre. (DERRIDA, 1994, p. 116-117).

A própria coisa se esquiva sempre. A coisa, a palavra e o labirinto se esquivam da compreensão final, do ato de encerrá-los em um sentido, uma estrutura. Todo esforço catalográfico, todo esforço estruturante, não é capaz de se esquivar da disseminação, efeito em que os sentidos se desmancham umedecidos pelas linhas de fuga ${ }^{2}$ que os três avatares disparam. Resta-nos deixar a disseminação falar de si, como uma peleja cordelística, em que personagens, sujeitos, autores, leitores e discursos alternam vozes, entre modos de fala e modos de escuta.

\section{A PELEJA}

Sobem as cortinas, honorável público, temos a honra de pisar este palco pela primeira vez em mui distantes terras para apresentar a peleja entre Zé Kinoscópio, o cangaceiro/revolucionário de câmera lenta e veloz, caboco filmador de sertão e cidades, o herói Kidwood, fazedor de justiça do primeiro mundo, para quem o bem e o mal não se confundem branco é

Simplificadamente podemos afirmar que a desterritorialização é o movimento pelo qual se abandona o território, "é a operação da linha de fuga" e a reterritorialização é o movimento de construção do território (DELEUZE; GUATTARI, 1997, p. 224); no primeiro movimento, os agenciamentos se desterritorializam e no segundo eles se reterritorializam como novos agenciamentos maquínicos de corpos e coletivos de enunciação (HAESBAERT; BRUCE, [s.d.]) branco, preto é preto e a mulata não é a tal e a andeja Ana Cinésia, feminista, bandoleira, arma em riste, desconfiada que nem calango, contorna o centro para não se consumir de vez no sempre, e guarda nas lembranças a terra da promissão.

Mas, não se desesperem que a peleja não é perdida antes de jogada. E se as forças da maldade são maiores em número e belicismo, o Santo Guerreiro Cangaceiro de coração de celulose traz no peito a marca do Arcanjo Miguel, cuja balança vai fazer pesar a justiça divina sobre o riso mudo dos contentes e fazer falar o silêncio dos magoados acocorados no chão. Então, respeitoso público, peço-lhes a devida atenção para o jogo que se inicia que o resultado é duvidoso entre o Diabo de dragão em cauda, espeto e fogo nas ventas, esse Arcanjo de balança e precisão que a tudo enfrenta e essa Santa do pau oco que atravessa "nonada", para dizer quem é ladrão, quem é valente, quem luta pela justiça de homens e Deus, quem traz ganância, quem usura, que é sabichão, quem é que fura o bucho de quem nessa peleja de facão, corte, montagem, luz, câmera, ação.

\section{$2.1 \mathrm{KIDWOOD}$}

O avatar Kidwood fala em "Velocidade Maxima 5: operação Rio" (JUSTIN LIN, 2011). Pilotos americanos de corrida vão ao Rio de Janeiro enfrentar traficantes de droga e políticos corruptos (e para aceitarmos isso, já fica considerado que na Casa Branca as coisas andam na linha, segundo a ética protestante e o espírito capitalista) e voar e desviar de balas sobre os barracos da favela da Rocinha como guerreiros ninjas importados diretamente do Japão.

No filme de animação, Rio (CARLOS SALDANHA, 2011), uma arara azul, macho, morando sob a neve civilizadora de Minnesota vai para sua terra natal (que segundo graça na mais elementar biologia de pré-vestibular não seria a cidade do Rio, mas a caatinga do Estado da Bahia), fazer contato com uma fêmea de sua espécie, ser sequestrado por traficantes de animais, com a participação de um menino negro, des- 
truir o cativeiro do tráfico no morro da Rocinha (lugar preferencial para o tráfico de animais, claro) e ter filhos com a arara brasileira, fêmea selvagem, voluntariosa ou sestrosa, como diria Ary Barroso.

Em Blame it on Rio (STANLEY DONEN, 1984), americano de meia idade seduz e se deixa seduzir pela filha adolescente de seu melhor amigo e o lugar ideal para se realizar esse tipo de transgressão, claro, são os tristes trópicos, cidade do Rio, com mulheres de seios a mostra e maconha a céu aberto. Em Orquídea Selvagem (ZALMAN KING, 1990), a cidade do Rio agora é alvo do poderoso capital imobiliário multinacional. Em meio à trama milionária em que se negocia a construção de um resort na praia, macumba para gringo, nudez, sexo, alucinações, toda a perversidade que os trópicos a preços módicos oferecem como elixir à palidez emocional ou à perversidade moralista do estrangeiro que sempre chega do frio.

Em Holocausto Canibal (RUGGERO DEODATO, 1980), um grupo de pesquisadores americanos adentra a floresta amazônica, virgem, enlouquece com o calor e os gases equatoriais, barbariza tribos "primitivas" que se assemelham a homens da caverna (o ícone mais caricato que o exotismo inventou nos signos cinematográficos dos mitos de origem) que se revoltam e devoram os tais pesquisadores estrangeiros.

Por fim, em Anaconda (LUÍS LLOSA, 1997), a floresta amazônica é o lar de uma cobra do tamanho do gorila King Kong. Um caçador, meio nativo (encenado pelo ator americano John Voight), enlouquece e mata, com a ajuda da cobra, todos os gringos de uma expedição, menos a mestiça, meio índia, meio latina, encenada por Jennifer Lopes, falando inglês e espanhol fluente na Amazônia brasileira.

Esses discursos seriam cômicos, não fossem poderosas armas ideológicas do cinema contemporâneo estadunidense que inventa o Brasil (e por extensão o terceiro mundo), sob o signo cidade-selva, selva que em parte, nunca deixamos de ser/pertencer aos olhos do colonizador e do missionário. Atualizam, ou melhor, operam a sobrevida dos estereótipos oitocentistas que dizem do civilizado e do primitivo sob o paradigma da matriz européia ocidental, da moral protestante cristã e do espírito capitalista que se inscreve a partir do indivíduo, da propriedade e da liberdade de se impor essas duas condições de dominação sobre os "outros" da civilização que não são considerados, nem indivíduos, nem proprietários.

Seriam cômicos e infantis, não fossem discursos que alavancam signos de poder. Signos que sustentam e retroalimentam percepções de subdesenvolvimento, terceiro mundo, trópico, ausência de leis, de linguagem, de civilização. Signos que se encontram presentes desde a literatura inglesa do século XVIII, desde a pintura de Gauguin, desde a gravura de Debret e a fotografia de Marc Ferrez, com seus coqueiros, macacos e selva ao fundo da civilização mal assentada. Desde o cinema de Carmem Miranda com suas bananas, seu sotaque, seu tipo exótico, perverso. Desde o Zé Carioca, com sua malandragem, tipo exportação, que reafirma a presença da América que a América protestante negou. Preferiu dar prosseguimento ao extrativismo da coroa britânica e arrancar desse chão suado, gorduroso e umedecido pela lasciva: o ouro, a fruta, o sumo, o sangue, o suor, o sémen, o futum, mas, também, a quiáltera, a instabilidade, a liberdade do jeito de corpo.

Esses discursos seriam cômicos não fossem grandes sucessos de bilheteria entre as décadas de 1980 e 2011. Filmes destacados de forma quase aleatória, porque exemplos assim se multiplicam desde muito antes do cinema de Carmem Miranda e Zé Carioca, pelo menos, desde que o europeu precisou inventar um estranhamento binário para dizer civilizado e bárbaro. Por isso, Kidwood é lindo, loiro, pragmático, alto, forte e romântico como um torpedo bancário.

O problema é que nós, latino-americanos, aprendemos a gostar, e pior, tentamos imitar, ainda que nos falte recursos para financiar produções do tipo "blo- 
ckbuster" hollywoodiano. E, assim, seguimos para o território da cópia, quase sempre caricata, que será devidamente ridicularizada pelos signatários da grande civilização da América do Norte, legítimos proprietários e representantes dos verdadeiros signos de heróis.

Assim, nossas cópias jogam “paintball” numa academia de São Paulo, tendo por inimigos os negros, quase negros, quase si, e põem na passarela do samba a ararinha "blu", como destaque do carro alegórico, e aprendem a ser idiotas com as mulheres que se fazem facilmente de idiotas em correspondência ao tal signo dominador. Branco, proprietário e macho. E assumem a indústria da diversão, da farmácia, da alimentação, dos esportes de espetáculo, combate e resultado, da estética, da moda, da segurança. E todo o entrecruzamento desses mesmos signos, reproduzindo territórios da habitação como isolamento, dos relacionamentos como perversão imagética de conquista, posse e resultado, da comida como máquina de entretenimento, da saúde como máquina de exclusão e seleção entre privilegiados e cabras marcados para morrer.

Com menos dentes na boca, a plateia da periferia ri das enrascadas e malabarismos de Kidwood, seja o original anglo-saxão seja o simulacro macho-latino. Aprovam sua coragem e velocidade na hora de discernir entre o bem e o mal. Pragmático, direto e simples. Kidwood só não tem discurso pronto sobre os desequilíbrios de distribuição de recursos entre territórios e classes sociais, sobre a fome, sobre a dor, a angústia e as ausências que não são resultado do tiro que o bandido deu no herói ou na família do herói.

Cabe ao acadêmico (nós, de fora da peleja) torcer para que um vazio se estabeleça entre o espectador terceiro-mundista e o herói americano (ou sua cópia). Torcer por um vazio que encha o espectador de senso crítico, de autorreflexão. Mas, Kidwood tem a capacidade de preencher essa autorreflexão, esse vazio, com velocidade máxima, violência e sexo em dose familiar. 0 vazio, assim preenchido, anestesia o es- pectador frente ao monstro que emerge da lagoa na canção de Chico Buarque e Gilberto Gil³.

Por fim, sugiro que não se deva nem descartar, nem se fixar demais nessa imagem do monstro, porque se ela está o tempo inteiro diante de nós, quase sempre, passamos por ela de forma despercebida. 0 mendigo vomitando comida podre dias antes de sua morte não-anunciada, a criança prostituída e drogada, a família nos escombros de um prédio que foi abandonado momentaneamente pelo capital, o trabalho forçado nos canaviais, sob o olhar atento das cascavéis de fuzil na mão, os cães e gatos vadios, perebentos, moribundos, vez por outra, atropelados e só lembrados pela limpeza urbana. E talvez já seja hora de pararmos com essas imagens. 0 vazio nos olhos é tão difícil de preencher que só mesmo um herói “latino-saxão”, um Kidwood, poderia encarar essa missão.

\subsection{ZÉ KINOSCÓPIO}

Emergido dos ermos rincões de sertão e veredas roseanas, moviola na mão, facão na outra, eis que surge para lhes redimir, será? Redenção? Qual redentor, messias, herói? Americano? Não. Deve haver outra dicção para Zé Kinoscópio falar de seu terceiro-mundismo, suas periferias, tudo em preto e branco, apavorante e fabuloso, belo e sublime, poeticamente sem recursos, paupérrimo, sem grua, sem som direto. Imagem crua gravada na carne, a câmera percorre as costelas do Eldorado, um gavião em penacho, um avião voa baixo, no País de São Saruê(VLADIMIR CARVALHO, 1971) ${ }^{4}$.

E são tantas e tamanhas imagens que o tempo bíblico e profético que inaugura a escritura-sertão pararia para ver e dar passagem. As pelejas, os causos, o pó virando sertão que depois vai virar mar e vai migrar pela Itapemirim, caravana “Rolidei”, Bye Bye Brasil (CACÁ DIEGUES, 1980), cruzar o país e empilhar andaimes no céu e vai ficar tão alto que anaconda vira minhoca no anzol do

3. Cálice (Chico Buarque e Gilberto Gil, 1973).

4. Citação a letra da música: "O país de São Saruê" de Luis Gonzaga, José Siqueira e Marcus Vinícius, 1971. 
Jeca Tatu (MILTON AMARAL, 1959), que, velozes e furiosos, não serão como o raio, rastro do pavão inventado e pilotado por Zé, e esses kidwoodsde araque não passarão de incautos imberbes, frente à fúria contagiante que elenca os elementos da natureza à destreza de se dizer reinventando as palavras, as imagens-palavras, maquinário de desfazer o querer-dizer maniqueísta.

Zé Kino que nasceu Zé Quirino, mas se reinventou por amor ao cinema, quando ainda menino o pai levou pra ver Mazzaropi, nem herói, nem bandido, o Jeca Tatu, depois Macunaíma (JOAQUIM PEDRO DE ANDRADE, 1969), o Mário de Andrade, depois, a malandragem de Jorge Amado, a Dona Flor e seus dois maridos (BRUNO BARRETO, 1976) de Vadinho, o saber desconstrutor de Diadorim e Riobaldo em Grande sertão: veredas (GERALDO SANTOS PEREIRA, RENATO SANTOS PEREIRA, 1965) que cruzam a língua dos bichos com a dos doutores, a revolta de Glauber, nem deus, nem o diabo, nem santo guerreiro, nem dragão da maldade, que o cangaceiro em desespero cumpre a promessa de não deixar o povo morrer de fome, passando a faca ou fuzilando um a um que cruza seu caminho, Deus e o Diabo na terra do Sol (GLAUBER ROCHA, 1968). Mas, antes de morrer agita os braços no ar qual bandeira em dia de festival e grita: "mais forte são os poderes do povo".

É nessa indefinição que os trópicos se definem? Não como exclusividade. Acredito que ela se expresse em todo lugar em que o capital não seja: nas estepes de Dostoievski, nas canoas maori da Revolução dos cocos (DON ROTHEROE, 2000), nas pradarias da Mongólia nômade, onde os Camelos também choram (BYAMBASUREM DAVA, 2003) no Saara berbere do poema visual Baba Aziz O Príncipe Que Contemplava Sua Alma (NACER KHEMIR, 2006), possivelmente o filme mais lindo já realizado até hoje, na Índia das monções de alagados arrozais, a denúncia de exploração do trabalho no campo em MotherIndia (MEHBOOB KHAN, 1957) em contraste com a denúncia da exploração do trabalho infantil na megalópole desumana em Salaam Bombay (MIRA NAIR, 1988).
Mas, possivelmente, é tudo invenção também, esperança de saída, de respiro para além da lógica truculenta que diz ou herói ou bandido, escolha seu lado. Ainda assim, Zé, estaria mais bem equipado para responder problemas emergenciais sobre a fome, a pobreza, as injustiças sociais, os desequilíbrios globais e locais, a guerra, a violência, o medo. Isso, não por ser mais rápido, mais rico, mais alto e forte, mas por não se meter ingenuamente a sair por aí elegendo a cada filme um novo Bin Laden, Saddan, Fidel, Evo, Hugo, Che, Lamarca, Lampião, Pancho Villa, Allende, signos de heróis ou bandidos à conveniência do leitor.

Em movimento, propõe-se então outro problema, nem cidade nem selva, por entre um sertão letrado/ analfabeto de casas grandes freyreanas, meninos de engenho, índias iracemas, diadorins, macunaimas, e que já se esparrama pela nova cinematografia póscolonial, de identidades territorializantes ${ }^{5}$, regionalizantes, que diz nordeste, que diz sertão, que diz cidade e selva, mas, como labirinto inconcluso, conspurcado inclusive pelo "american way of life". Labirinto, cujas rizomificações desfilam imagens elencadas de uma cinematografia que permite dizer simultaneamente: sertão, mar, cidade, selva, cangaço, engenho, subdesenvolvimento, planejamento estratégico, coqueiro, rede na varanda, cobertura de luxo de frente para o mar, resort com paraíso ao fundo.

Nem logos, nem mito, fala-se então de uma terceira margem proposta na expressão de hipertextualidade entre Guimarães Rosa, Jorge Amado, Graciliano Ramos, José Lins, Vladimir Carvalho, Nelson Pereira, Eduardo Coutinho, Glauber Rocha,Silvio Tendler, Cláudio Assis e o novo cinema pernambucano: Aspi-

5. A noção de território aqui é entendida num sentido muito amplo, que ultrapassa o uso que fazem dele a etologia e a etnologia. Os seres existentes se organizam segundo territórios que os delimitam e os articulam aos outros existentes e aos fluxos cósmicos. 0 território pode ser relativo tanto a um espaço vivido, quanto a um sistema percebido no seio da qual um sujeito se sente "em casa". 0 território é sinônimo de apropriação, de subjetivação fechada sobre si mesma. Ele é o conjunto de projetos e representações nos quais vai desembocar, pragmaticamente, toda uma série de comportamentos, de investimentos, nos tempos e nos espaços sociais, culturais, estéticos, cognitivos (GUATTARI; ROLNIK, 1986, p. 323). 
rinas e Urubus, Baixio das Bestas, Árido Movie, Baile Perfumado, Amarelo Manga, Céu de Suely, Deserto Feliz. Em questão, a desconstrução reterritorializante como ato político de dizer Brasil.

Ainda resta uma questão guardada nas entrelinhas do texto de Zé Kinoscopio, e que o próprio avatar prefere não destacar, não fazer alarde. Essa questão inquire Kinoscopio sobre o lugar preferencial do corpo da mulher nos textos desse cinema intelectual que nessa hora revela sua faceta de macho-ibérico, conquistador, dono do corpo feminino. A mulher escolhida pelos olhos de uma câmera, via de regra, tão atenta as questões de dominação e exploração, mas que nessa seara torna-se míope, e se aproxima vertiginosamente da estética da narrativa de Kidwood. Mulher -objeto, mulher-bunda, mulher-peito e cochas, mecanismo autômato, bonecaviciada em atender aos olhos dos homens que filmam e assistem.

Melhor que o nosso cinema, a música de Caetano estampou a ignorância do macho,"ninguém sabe

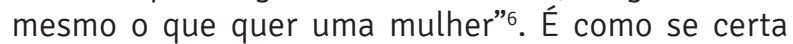
qualidade de autores e intelectuais de esquerda, do centro e da periferia do mundo, se tornasse cega pela paixão estética, cultural, a ponto de não conseguir enxergar entre músicas, danças, cerimônias e cenas do cotidiano comunitário, arcaico e protocapitalistado "outro", encantado pela antropologia e pela narrativa cinematográfica, os maus tratos, os espancamentos, os estupros, o silenciamento e a dominação bruta que, via de regra, subjuga o lugar da mulher nesses cenários em que predominam os modos tão festejados da tradição da vida comunitária, espécie de resistência local ao modo de vida capitalista, moderno, individualista, pragmático e globalizado.

Quando o discurso de Zé Kinoscópio encampa e até estimula as formas de dominação tradicional, inerentes a configuração étnico-cultural-religiosa expressa nas organizações comunitárias (povoados, vilas, su-

6. Pecado original (Caetano Veloso, 1993). búrbios, quilombos, tribos), não percebe o quanto naturaliza o tratamento dispensado ao corpo da mulher na tela de cinema. Assim, se a imagem do corpo da mulher na tela do cinema de Kidwood, é, via de regra, subjugada e reificada em função da imagem do herói americano, espécie de troféu que cabe ao protagonista ao termino da saga vitoriosa, na tela do cinema de Kinoscópio esse lugar, além de ser fortemente marcado pela dominação e exposição do corpo, guarda ainda o agravante da naturalização dos maus tratos, prática menos presente em sociedades modernas, em que o direito cidadão da mulher, está garantido pela normatividade da lei e de sua interiorização nas práticas cotidianas.

Mas, esse tema, da exploração do corpo feminino pelo olhar de Kidwood e de Kinoscópio é um assunto para Ana Cinésia. Como disse Lennon, um intelectual de esquerda sensível a essa questão, "Womanis the nigger of the world", a mulher é o negro do mundo.

\subsection{ANA CINÉSIA}

Entre as trilhas cismadas de Zé Kinoscópio e os devaneios incautos de Kidwood, Ana Cinésia entra nessa peleja em outra invenção que não é a América Tropical da Arara "Blu” e nem o iconoclasta prostíbulo da cidade maravilhosa que se deita no Rio. Entra com a caravana "Rolidei" empinando papagaios de barbatanas coloridas que se fincam nas espinhas de peixe ou se vão soltos, ao langor dos ventos altos depois que a linha foi cortada por cerol. Entra pelas ruas enlameadas de chuvas e dejetos, onde à noite sapos e grilos escondem outros dizeres e cachorros pulguentos, magros e mudos perambulam nus. Entra no "Inferno Verde" não como Amazona com um seio queimado para melhor empunhar o arco, como aquelas da mitologia heróica da antiguidade clássica que se firmam em nosso folclore, mas como Natyseño ${ }^{8}$ da língua Terena. Entra por meio do "espelho de próspero", fincando pé no mirador de Rodó (1991), tentando desvanecer os

7. Woman is the nigger of the world, John Lennon, 1972

8. Natyseño - Palavra na língua Terena, Mulher Forte, Guerreira (CoNAMI, 2006) 
olhos do jogo vetusto entre a face anglo-saxônica e a face ibérica do "Novo Mundo": labirinto da solidão.

De sertão em sertão, entre rios e mares, entre montanhas e vales, entre pobreza e primitivismo há muitas histórias para contar. Interior e autenticidade, excêntricos signos inventados por um romantismo utópico, mas não fora do logos do próprio ocidente. Um logos às avessas, que não desfuncionaliza o ideal estético modernista, cuja atitude cultural é a busca de uma experiência autêntica. Só que essa experiência não é possível no mundo moderno, então se reproduz na ideia de interior os signos natureza; selva; primitivo; trópicos. "Tristes Trópicos” que Lévi-Strauss, desencantado, encontrou em 1938 quando chegou ao Brasil. E como um lucreciano, não pode fazer sua "psicoterapia ética”, pois os Nhambiquaras "belos, nus, indigentes, nômades” dos registros de 1915 feitos pela primeira visita dos missionários brancos, estavam desabando, tornando-se miseráveis, feios e sifilíticos (SONTAG, 1987, p. 90).

Um flanêur baudelairediano nos igarapés dos trópicos. Se a experiência autêntica dos modernistas enreda primitivo/selvagem/autêntico, quando incorporada no pensamento de cinema no Brasil na contemporaneidade aloca-se nos avatares da periferia e da pobreza, nas vísceras expostas dos amarelos. 0 Brasil da periferia e pobre alimenta os olhos dos intelectuais românticos da América do Norte e Europeus, incidindo no estrabismo do nosso olhar colonizado sob os auspícios da pobreza como exotismo e como condição de alteridade. Há quem o diga Baixio das Bestas; Deserto Feliz; Anjos do Sol.

Então, também, entre pobreza e primitivismo, chega de bater punheta com prostituição de mulheres no cinema brasileiro. Baixio das Bestas (CLÁUDIO ASSIS, 2006); Deserto Feliz (PAULO CALDAS, 2007); Anjos do Sol (RUDILAGEMANN, 2006). Três olhares sobre as mulheres no cinema nordeste. Sim, Kidwood, mostre seus esquecimentos, mostre em que rios do grande LETE depositou as agruras do feminino do imaginário dos homens!9 No Deserto Feliz por meio da trajetória de uma adolescente violentada pelo pai que sai do sertão nordestino para trabalhar como prostituta até conhecer um turista que a leva a Berlim? Ou no Baixio das Bestas, por meio da vida de uma adolescente de 13 anos que é explorada pelo avô à noite exposta nua para ser observada por homens que pagam alguns vinténs para isso? Ou ainda com os Anjos do Sol, no drama de uma menina de 12 anos do interior do nordeste brasileiro vendida pela família a um recrutador de prostitutas que a envia para uma pequena cidade na floresta amazônica?

Chega de o território rústico ser inscrito num nordeste como signo de "sem destino"! Chega de ser tragicamente instituído sob o signo da ausência e determinado pelo olhar insuficiente de um futuro sem escolha, invenção com nítido descompromisso com uma poética do real. Essa sim abre possibilidades de se inscrever outros advires. Estes filmes não fazem isso com as mulheres nem com a pobreza, mas ratificam o destino feminino nas agruras do modelo hegemônico de masculinidade. 0 que se assiste nesses filmes é a reprodução de um referente social, mutheres pobres, cujos traços e componentes enquanto personagens se feitam nas imagens que as criaram.

O self-made-man, cuja emergência histórica advém dos Estados Unidos e Europa Ocidental do século XVIII até o presente, transformado em ideal hegemônico pela indústria cinematográfica das versões hollywoodianas. As masculinidades são constituídas de relações de poder, que podem ser vistas nas relações de homens com mulheres, bem como nas relações dos homens com outros homens. Em meio a qualquer sociedade, em qualquer momento, há múltiplos sentidos de o que ser homem significa. Masculinidades no plural significam diferentes coisas para diferentes grupos de homens em diferentes momentos.0 modelo ideal hegemônico de masculinidade foi constituído sob o suporte da ideia de homem civiliza-

9. É como a máxima de Édouard Herriot (APUD WEINRICH, 2001): "A cultura [...] é o que permanece no homem quando ele tudo esqueceu". 
do, da burguesia sob a égide do capitalismo, da personalidade democrática individual, da ética do trabalho protestante e do espírito da racionalização do capitalismo, e sob o ego autônomo (KIMMEL, 1998).

Anjos do Sol (RUDI LAGEMANN, 2006) meninas do sol, aplacadas pelos "Filhos do Sol" (ordem patriarcal), precisam de seus demônios para fugir desse designo agônico em arena cujo cenário é o poder vencedor do herói que sempre dá certo. A prostituição de meninas sob o embalo de músicas do cancioneiro afetivo popular naturaliza um signo de poder, essencializa um troféu depois de horas de trabalho árduo no garimpo, além de legitimar um desdizer, pois o foco narrativo nem sequer espreita a perspectiva do sujeito mulher.

Junção estrábica de Kidwood e Kinoscópio, como cinema intelectualizado e heroicizado à custa de corpos pornografados em dicção perversa e esquizofrênica. A Incrível e Triste História da Cândida Eréndira e da Sua Avó Desalmada, conto de Gabriel García Márquez (1974), na versão cinematográfica Erêndirade Ruy Guerra (1983) se afina com a Incrível e Triste História da Auxiliadora e de Seu Avô Desalmado no Baixio das Bestas (CLÁUDIO ASSIS, 2006). Novamente do mirador de Rodó, o labirinto da solidão. 0 autor em um incêndio acidental leva Cândida Eréndira a um triste fado: ser prostituída por sua avó desalmada para recompensar as perdas. Cláudio Assis em cena cinematográfica leva Auxiliadora a uma triste sina: ser voyeur para o onanismo de homens calados, sem onde apegar, a maioria caminhoneiros, em um tempo que engole a usina e que engole a todos nós - Zona da Mata Canavieira. Cláudio Assis inscreve no silêncio de Auxiliadora o lastro ausente do familismo ancestral engolido por um avô que não pertence aos contos de fada - "Tem muito caminhoneiro! Agente vai no Posto, que o movimento está é bom".

Sem rastros, Deserto Feliz (PAULO CALDAS, 2007) entre Petrolina, Juazeiro, Recife e Berlim, atraca em gestos surdos o destino de Jéssica(s) "tão sem destaque", em "suítes presidenciais... fazendo gostoso"....
Um padrasto abusa de sua enteada sob o signo da caça no Deserto Feliz. Feliz para quem? Para os caminhoneiros dos postos de gasolina e para os gringos que "gostam de ver as coisas, as pernas..." As mulheres têm sina, não têm vida. As expectativas impostas a elas são por meio de repertórios de uma pobreza exótica crivada nos cenários masculinos em que as mulheres não são vistas. Jéssica foge do Deserto Feliz com um caminhoneiro que diz em seu pára-brisa que "Deus é Fiel".

Nesse sentido, levando em conta a inscrição das mulheres nos filmes e o pensamento que eles criam sobre elas, é bom lembrar com Laura Mulvey (1975) que o cinema clássico hollywoodiano, falocêntrico e estruturado no inconsciente da sociedade patriarcal, teria inventado uma mulher com os atributos da capacidade de manipular e articular de maneira satisfatória o prazer visual. Isto significa que o sistema de pensamento nessas narrativas fílmicas, industriais e intelectuais, está nitidamente inserido na ideologia patriarcal.

A mulher no cinema tem funcionado basicamente de duas maneiras: como objeto erótico no filme e como objeto de contemplação fora dele. Digo novamente do mirador de Rodó (1991), Kinoscópio, precisamos de arte e não de exotismo romântico às avessas nos signos Nordeste, mulher e pobreza.

\section{RISCO DE FACA NO CHÃO: FIM DA PELEJA}

Não é fácil ser herói, apesar das vantagens inerentes ao cargo que os discursos do tipo Kidwood abraçam sem questionamentos. Fora dos espaços de cena, a cocaína, o consumo de novas tecnologias, o isolamento glamouroso ou a superexposição no luxo do tapete vermelho, a mansão, a limusine, as viagens de jatinho e, principalmente, a sensação de possuir um corpo espetáculo, ajudam, ou deveriam ajudar os discursos do tipo Kidwood a suportar a condição traumática de macho ibero-americano. Os afagos da inteligentzia, o domínio dos termos da nomenclatura, o passe livre ao ethos formado pelos espaços das 
universidades, dos festivais, dos cineclubes descolados, dos cinemas alternativos e dos núcleos criativos da narrativa cinematográfica permitem ao escopo discursivo do avatar Kinoscópio dar salvas aos parangolés da favela de Oiticica, a revolução estética das novas linguagens, mas também, aplaudir o gingado, a reza, o toré, o xangô, o rabo de arraia, a cachacinha na birosca, a casa de taipa, tão bem construída pelas artimanhas da sabedoria popular, o equilíbrio da lata d'água na cabeça, as tecnologias da cacimba e do melaço, o artesanato de penas de pássaros, sementes, barro e madeira.

Kinoscópio pode descer ao mais fétido puteiro de posto de gasolina, se encantar com suas luzes neon, suas cores desbotadas, a pele das putas carcomidas pelo uso cotidiano, depois transcreve tudo para a tela com belas moças da classe média urbana que a custa de alguma maquiagem e laboratório com as putas reais fazem a vez dessas para alegria dos homens de dentro e de fora da tela. Ana Cinesia, renunciando as besteiras de menina agora tem que se defender desse facão guarani, que o trem tá feio ${ }^{10}$. 0 lugar da mulher nesse jogo de forças brutas, não é fácil, e ela precisa da astúcia e meia de Pedro Malasartes, da malandragem e meia de Madame Satã, da artimanha e meia de Jeca Tatu, para escapar das armadilhas da sorte que os olhares de Kidwood e Kinoscopio lhe reservam.

Resta torcer para que hoje seja o dia da caça, porque todo dia, via de regra, é dia do caçador. O lugar dessa imagem de mulher no cinema está determinado muito antes do cinema ser inventado, pelo menos desde quando o poeta florentino, Marcilio Ficino questionou o que seria mais apreciado pelo visitante a imagem ou a descrição do lugar. Leonardo Da Vinci, contemporâneo do poeta, também pergunta: "Se possuirmos a imagem de uma pessoa amada ou um poema sobre essa pessoa, a qual daremos preferência?" (BAVCAR, 2004, p. 145). Bavcar assume que quando se trata da imagem de uma mulher essa questão se

10. 0 trem tá feio (Tavinho Moura e Murilo Antunes, 1996) potencializa. "A que dar a prioridade uma vez que, seja qual for o estado em que ela seja representada pela imagem ou exaltada pela poesia, ela, em carne e osso, não está mais lá?” (BAVCAR, 2004, p. 146).

Mas a pergunta seria, anterior a essa dupla possibilidade de representação, a pergunta é por que o corpo da mulher? Por que a ausência a ser preenchida pertence ao campo do desejo inscrito pelo olho masculino? Por que o desejo, a fala, a querência feminina é sempre um silencio, uma incógnita, uma interrogação? Afinal ninguém sabe mesmo o que quer uma mulher. A pergunta de Bavcar dobra-se sobre ela mesma, quando se questiona porque o desejo necessita de uma imagem, porque o desejo não vai direto ao ponto.

A melhor resposta a essa questão encontra-se na própria dobra discursiva do pós-estruturalismo, como proposto por Zizek (2013). Não se trata de perguntar por que o cinema explora a imagem da mulher, mas por que o desejo, que, em nossa sociedade, sempre pertenceu ao campo do masculino, precisa da imagem da mulher para se satisfazer. Fechamos essa apresentação com duas falas consecutivas de Zizek que silenciam as queixas, protestos e bravatas, respectivamente, de Ana Cinesia, Zé Kinoscopio e Kidwood.

[...] se olharmos nossas experiências diárias mais comuns, de nós mesmos e de outros, [...] a maneira que nós imediatamente a experienciamos, nós apagamos, extraímos a partir da imagem da outra pessoa, nosso parceiro, determinadas características, que são simplesmente muito embaraçosas para serem mantidas em mente o tempo todo. Tipo, eu falo para você: claro que racionalmente eu sei, você está defecando, você está suando, para não falar outras coisas, mas, literalmente, quando eu interajo com você, isso não faz parte da imagem que eu tenho de você. Portanto, quando eu lido com você, eu não estou basicamente não lidando com o seu real. Estou lidando com a imagem virtual de você. E esta imagem tem uma realidade, no sentido de que ela estrutura o jeito que eu lido com você. E então essa idealização é crucial. [...] imagem virtual que determina como nós interagimos com outras pessoas. Imagem virtual, no sentido de: embora nós interagimos com pessoas reais, nós apagamos, nos comportamos como se todas as "camadas” da outra pessoa não existissem (ZIZEK, 2013). 
Pegue a pílula azul, a história acaba e você acorda em sua cama e acredita em qualquer coisa que você quiser. Pegue a pílula vermelha e você permanece no mundo das maravilhas, e eu the mostro o quão profundo e aonde leva a toca do coelho. Mas a escolha entre a pílula azul e vermelha não é na verdade uma escolha entre ilusão e realidade. [...] Eu quero uma terceira pílula! E o que é a terceira pílula? [...] uma pílula que me permita perceber - não a realidade por trás da ilusão - mas a realidade na ilusão em si mesma. Se algo fica muito traumático, muito violento, muito cheio de prazer [...] nós temos que "ficcionalizar". Sexualidade nunca é somente eu e minha parceira (ou parceiros, seja lá o que você estiver fazendo), tem sempre um elemento fantasmagórico, um elemento de imaginação fértil que permite que eu me envolva na sexualidade. Há uma fascinação irresistível em nós, pelo menos para mim, nesta cena horripilante, quando Neo acorda da Matrix e toma consciência do que ele realmente é naquele contêiner fabril, imerso naquele líquido e conectado à realidade virtual, onde você é um objeto completamente passivo com sua energia sendo sugada de você. Então porque a Matrix precisa de nossa energia? Acho que a forma adequada de fazer essa pergunta é mudá-la para a questão: não porque a Matrix precisa da energia, mas porque a energia precisa da Matrix. Quer dizer, acho que a energia de que estamos falando é a libido, nosso prazer. Porque nossa libido precisa do universo virtual de fantasias? Porque não podemos simplesmente apreciar diretamente? Um parceiro sexual e por aí vai, esta é a pergunta fundamental. Porque precisamos desse suplemento virtual? Nossa libido precisa de ilusão para sustentar a si mesma. (ZIZEK, 2013).

\section{FIM DA PELEJA}

0 apresentador sobe ao palco e dirige-se para a plateia. "Agradecemos a tão distinta audiência por sua atenção e interesse, esperando ter-lhes proporcionado diversão, cultura e entretenimento. Esperamos revê-los em breve com novas aventuras, cheias de picardia e emoção". Kidwood sobe ao palco ovacionado de pé pelo público ouvinte, recebe do apresentador um ramalhete de flores vermelhas, inclina lisonjeiramente o corpo agradecendo a mui amável plateia.

O gesto de entrada é repetido por Zé Kinoscopio, também muito aplaudido, nessa hora, Zé dá um afetu- oso abraço em Kid. Kid confidencia algo inaudível aos ouvidos de Zé que retribui com sorrisos e afagos. Por fim, Ana Cinesia retorna ao palco e o público vai ao delírio, gritos de bravo, são ouvidos de todos os lados da plateia, flores são jogadas aos pés da dama, que retribui o carinho com beijos e gestos afetuosos direcionados ao público.

Kid e Zé abraçam, um de cada lado a cintura de Ana. Os três em gesto coordenado se inclinam em agradecimento, as cortinas baixam. 0 público de pé, aplaude emocionado. As cortinas tornam a subir, o público vai ao delírio, mais palmas e gritos de bravo! Depois de três ou quatro subidas e descidas de cortina finalmente as luzes se acendem de vez e o público caminha em direção as saídas. Na coxia, os três avatares retiram suas máscaras, com indiferença, silencio e cansaço.

\section{REFERÊNCIAS}

ANDRADE, Joaquim Pedro de. 1969. Macunaíma. Brasil. Duração 110 minutos

ASSIS, Cláudio. 2007. Baixio das Bestas. Brasil. Duração 80 minutos

AMARAL, Nilton. 1959. Jeca Tatu. Brasil. Duração 95 minutos.

BAKHTIN. Mikhail. Estética da criação verbal. São Paulo: Martins Fontes, 2003.

\section{BARRETO, Bruno. 1976. Dona Flor e seus dois}

maridos. Brasil. Duração 120 minutos.

BAVCAR, Evgen. A imagem, vestígio desconhecido da luz. In: NOVAES, Adauto. (Org.). Muito além do espetáculo. São Paulo: Senac, 2004.

BENJAMIN, Walter. Origem do drama barroco

alemão. São Paulo: Brasiliense, 1984. 
CALDAS, Paulo. 2007. Deserto Feliz. Brasil. Duração 88 minutos.

CARVALHO, Vladimir. 1971. País de São Saruê. Brasil. Duração 90 minutos.

CONAMI (org.) Natyseño: tragetória, luta e conquista das mulheres indígenas. Belo Horizonte: FALE/UFMG, 2006.

DAVA, Byambasurem. 2003. Die Geschiche Von Weinenden Kamel (Camelos Também Choram). Alemanha/Mongólia.Duração 87 minutos.

DEODATO, Ruggero. 1980. Canniba Holocaust (Holocausto Canibal). Itália. Duração 96 minutos.

DERRIDA, Jacques. A voz e o fenômeno. Rio de Janeiro: Jorge Zahar, 1994.

DERRIDA, Jacques. Salvo o nome. Campinas, SP: Papirus, 1995.

DIEGUES, Caca. 1980. Bye Bye Brasil. Brasil. Duração 105 minutos.

DONEN, Satanley. 1984. Blame it on Rio. (Feitiço do Rio). Estados Unidos. Duração 100 minutos.

GUATTARI, E; ROLNIK, S. Micropolítica: cartografias do desejo. Petrópolis: Vozes, 1996.

GUERRA, Ruy.1983.Erêndira. Brasil. Duração 103 minutos.

HADDOCK-LOBO, Rafael. Derrida e o labirinto de inscrições. Porto Alegre: ZOUK, 2008.

HAESBAERT, R.; BRUCE, Glauco. A desterritorialização na obra de Deleuze e guattari. [S.D.]. Disponível em: <http://www.uff. br/geographia/ojs/index.php/geographia/article/ viewFile/74/72>. Acesso em: 07 dez 2015.
KHAN, Mehboob. 1957. MotherIndia. India. Duração 172 minutos

KHEMIR, Nacer. 2006. Baba Aziz - 0 príncipe que contemplava sua alma França/Alemanha/Irã/ Tunísia/Reino Unido. Duração 96 minutos

KIMMEL, Michael. A Produção simultânea de masculinidades hegemônicas e subalternas. In: Horizontes Antropológicos/UFRGS. IFCH. Programa de Pós-Graduação em Antropologia Social. Porto Alegre: PPGAS, 1998.

KING, Zalman. 1990. Wild orchid (Orquídea Selvagem). Estados Unidos. Duração 103 minutos.

LAGEMANN, Rudi. 2006. Anjos do Sol. Brasil. Duração 92 minutos.

LAPLANTINE, François; TRINDADE, Liana Sálvia. 0 que é imaginário. São Paulo: Brasiliense, 2003.

\section{LÉVI-STRAUSS, Claude. Antropologia estrutural}

dois. Rio de Janeiro: Tempo Brasileiro, 1976.

LIN, Justin. 2011. Fast five (Velozes e Furiosos 5: Operação Rio). Estados Unidos. Duração 130 minutos.

LLOSA, Luís. 1997. Anaconda. Estados Unidos/ Brasil/Peru. Duração 89 minutos.

MACHADO, Roberto. Deleuze, a arte e a filosofia. Rio de Janeiro: Jorge Zahar, 2010.

MORIN, Edgar. As estrelas: mito e sedução no cinema. Rio de Janeiro: José Olympio, 1989.

MORSE, Richard M. 0 espelho de próspero: cultura e idéias nas Américas. São Paulo: Companhia das Letras, 1988.

MULVEY, Laura. Visual pleasure and narrative cinema. Screen, v. 6, n.3, 1975. p. 6-18. 
NAIR, Mira. 1988. Salaam bombay. Inglaterra / França/India 112 minutos.

PEREIRA, Geraldo Santos; PEREIRA, Renato Santos. 1965. Grande sertão: veredas. Brasil. Duração 92 minutos

ROCHA, Glauber. 1968. Deus e o diabo na terra do sol. Brasil. Duração 125 minutos.

RODÓ, José Enrique. Ariel. Campinas-SP: UNICAMP, 1991.

ROTHEROL, Don. 2000. The coconut revolution (Revolução dos Cocos). United Kingdom. Duração 50 minutos.
SALDANHA, Carlos. 2011. Rio. Estados Unidos/ Brasil. Duração 96 minutos.

SAMPAIO, Fernando G. As amazonas: a tribo das mulheres guerreiras - (A derrota do matriarcado pelos Filhos do Sol). São Paulo: Aquarius, s/d.

SONTAG, Susan. Contra a interpretação. Porto Alegre: L\&PM, 1987.

WEINRICH, Harald. Lete: arte e crítica do esquecimento. Rio de Janeiro: Civilização Brasileira, 2001.

ZIZEK, Slavoj. A Realidade do virtual. Filme legendado. 13/6/2013. Disponível em: <https://www.youtube.com/ watch?v=M4HdqlwVDpk>. Acesso em: 5 dez. 2015. 
1. Doutora em Antropologia pela UFPE; Pesquisadora do Núcleo Interdisciplinar de Pós-Graduação do Centro Universitário Tiradentes - UNIT/AL e do Instituto de Tecnologia e Pesquisa - ITP/UNIT/SE; Professora Titular I do UNIT/ AL; Membro do Grupo de Pesquisa Nordestanças/UFAL; Atualmente trabalha em Projeto Financiado pelo IPHAN. E-mail: jesanabpereira@gmail.com

2. Doutor em Planejamento Urbano e Regional pela UFRJ; Pesquisador do Núcleo Interdisciplinar de Pós-Graduação do Centro Universitário Tira-

dentes - UNIT/AL e do Instituto de Tecnologia e Pesquisa - ITP/UNIT/SE;

Professor Titular II do UNIT/AL; Líder do Grupo de Pesquisa Nordestanças/ UFAL. Atualmente trabalha em Projeto Financiado pelo IPHAN e CNPQ. Aceito em: 18 de dezembro de 2015

E-mail: walclerjunior@hotmail.com 